\title{
Wiktoria Gadziała
}

Kinga Chrobak

Studentki Uniwersytetu Pedagogicznego im. Komisji Edukacji Narodowej w Krakowie

\section{Studencka świadomość prawna}

\author{
https://doi.org/10.25312/2391-5110.14/2019_07wgkch
}

\section{Streszczenie}

Artykuł podejmuje problematykę zdefiniowania pojęcia świadomości prawnej. Wyjaśnia to pojęcie oraz wskazuje prekursorów przedstawiających to zagadnienie. Celem artykułu jest omówienie świadomości prawnej studentów pierwszego roku Instytutu Prawa, Administracji i Ekonomii na Uniwersytecie Pedagogicznym im. Komisji Edukacji Narodowej w Krakowie. Uwagę skoncentrowano jedynie na wybranych pytaniach, które według autorów sprawdzały wiedzę prawną docelowej grupy studentów.

Słowa kluczowe: świadomość prawna, studenci, znajomość prawa

\section{The legal awareness of students \\ Summary}

This article addresses the issue of defining legal awareness. It discusses the concept of 'legal awareness' and refers to the work of scholars who discuss this issue. The article presents the legal awareness of first year undergraduate students enrolled at the Institute of Law, Administration and Economics at the Pedagogical University of the National Education Committee in Cracow. The article focuses on the wording of questions that, according to the authors, help in the assessment of the legal knowledge of the target group of students.

Keywords: legal awareness, students, legal knowledge 


\section{Wprowadzenie ${ }^{1}$}

Pojęcie świadomości prawnej jest częścią kultury prawnej. Świadomość ta nie oznacza jedynie znajomości przepisów i instytucji prawnych przez społeczeństwo, ale również jest oceną obowiązującego prawa oraz krytycznego podejścia do wielu jego zmian. Ignorantia iuris nocet $t^{2}$ - ta rzymska paremia stanowi pewnego rodzaju ostrzeżenie dla wszystkich obywateli, gdyż nie ma żadnego usprawiedliwienia w momencie popełnienia błędu, który wynika z nieznajomości prawa. Autorki, za pomocą przeprowadzonych badań, podjęły próbę zdiagnozowania, czy i jak duża jest nieznajomość prawa oraz jakie może to mieć konsekwencje. W badaniach wzięli udział studenci pierwszego roku prawa, administracji i ekonomii społecznej jako przedstawiciele grupy studentów z dziedziny nauk społecznych. Głównym celem artykułu jest zweryfikowanie poziomu świadomości prawnej u studentów wyżej wymienionych kierunków w Instytucie Prawa, Administracji i Ekonomii Uniwersytetu Pedagogicznego im. Komisji Edukacji Narodowej w Krakowie. Badania zostały przeprowadzone na celowo wybranej grupie badawczej. Jej członkowie są na początku swojej drogi naukowej, dlatego autorki chciały sprawdzić, jak wygląda ich wiedza prawna po ukończeniu szkoły średniej.

\section{Świadomość prawna społeczeństwa polskiego}

„Świadomość prawna” to termin trudno definiowalny, ponieważ jest używany w wielu obszarach - zarówno na płaszczyźnie naukowej, jak i w obrocie społecznym. Rozważania nad tym zagadnieniem rozwijane są na podstawie koncepcji psychologicznych, psychospołecznych oraz mikro- i makrosocjologiczych, dlatego termin ten w każdej z dyscyplin naukowych może być przedstawiony z punktu widzenia różnych teorii, takich jak: kognitywizm, ewolucjonizm czy psychoanaliza. Warto jednak podkreślić, że są to tylko wybrane dyscypliny, z których perspektyw można patrzeć na świadomość prawną ${ }^{3}$. Jednym z pierwszych badaczy, który poddał świadomość prawną analizie, był L. Petrażycki. Nadał on jej następujące przymioty:

[...] wyrażenia te są tylko przekładem swoistych własności owej autorytatywno-impulsywnej emocji, na której opiera się imperatywno-atrybutywna świadomość prawna, na język wyobrażeń; aktywna, popędowa jej strona ma taki charakter, że odpowiedni impuls przeżywamy jako wewnętrzny przymus do przystosowania i podporządkowania swojego postępowania, czego się autorytatywnie wymaga od jednego dla drugiego ${ }^{4}$.

${ }^{1}$ Szczególne podziękowania składamy na ręce dr Urszuli Kosielińskiej-Grabowskiej oraz dra Wojciecha Maciejewskiego za wsparcie merytoryczne oraz edytorskie.

${ }^{2}$ M. Kuryłowicz, Stownik terminów, zwrotów i sentencji prawniczych łacińskich oraz pochodzenia tacińskiego, Wolters Kluwer, Warszawa 2012, s. 64.

${ }_{3}$ J. Czapska, Psychospołeczne watki w pracach Marii Boruckiej-Arctowej. Świadomość prawna, Zakład Wydawniczy Nomos Sp. z o.o., Kraków 2017, s. 11.

${ }^{4}$ L. Petrażycki, O pobudkach postępowania i o istocie moralności i prawa, Oficyna Naukowa, Warszawa 2002, s. 45. 
Według M. Boruckiej-Arctowej świadomość prawna definiowana jest jako jeden z kluczowych elementów, które kształtują proces tworzenia prawa oraz główny warunek skuteczności prawa, przez co istnieje ścisły związek z podstawowymi zagadnieniami socjologii prawa a świadomością prawną. Świadomość prawna oddziałuje zarówno na proces stosowania prawa przez organy państwowe, jak i na proces przestrzegania prawa przez obywateli, dlatego każda władza jest obowiązana zwracać uwagę na kształtowanie świadomości prawnej5.

Świadomość prawna społeczeństwa polskiego jest niska, na co wskazują badania przeprowadzone z inicjatywy kwartalnika Stowarzyszenia Sędziów Polskich Iustitia przez agencję badawczą Maison \& Partners na temat „diagnozy świadomości prawnej Polaków w 2016 r."6. Jak wynika z przeprowadzonych badań, zaledwie 36\% respondentów zdaje sobie sprawę, iż nieodebrane w terminie pismo z sądu, które zostało nadane listem poleconym i nie zostało odebrane ponowie w czasie awizowania, będzie uznane za doręczone, co w dalszej konsekwencji wywołuje skutki prawne dla danej osoby. Tylko 34\% badanych zdaje sobie sprawę, że apelacja, która została wniesiona po terminie, nie podlega rozpatrzeniu. Kolejne dane wskazują, iż ponad połowa Polaków uważa, że sędziowie należą do partii politycznych ${ }^{7}$. Jest to sprzeczne z art. 178 ust. 3 Konstytucji Rzeczpospolitej Polskiej, który brzmi: „Sędzia nie może należeć do partii politycznej [...]”. Z powyższych przykładów wynika, że społeczeństwo polskie przez niedostateczną wiedzę prawną może narazić się na negatywne konsekwencje prawne. Nasuwa się tu na myśl podstawowa paremia łacińska: ignorantia iuris nocet. Maksyma ta oznacza, że nieznajomość prawa szkodzi ${ }^{9}$. Wielu ludzi zna tę zasadę, jednak nie wdraża jej w życie, uważając to za zbędne. Dobrym przykładem braku nieznajomości prawa jest sytuacja, gdy pracownik myśli, że może z dnia na dzień zostać zwolniony z pracy bez uzasadnienia lub gdy przestał spełniać oczekiwania niezwiązane z wykonywaniem pracy, a jedynie z ustalonymi przez pracodawcę zasadami. Wynika to $\mathrm{z}$ faktu, iż obywatele polegają na swojej intuicji, mając nadzieję, że prawo działa w granicach zdrowego rozsądku ${ }^{10}$. Myślenie to jest błędne, gdyż każdy obywatel powinien mieć podstawową wiedzę prawną, jej brak może bowiem skutkować poważnymi konsekwencjami. Według J. Sobczaka, sędziego Sądu Najwyższego, osoby wykonujące zawody prawnicze, pracownicy korporacji oraz lekarze powinni mówić do petenta lub klienta jak najprostszym językiem ${ }^{11}$. Jednak często jest to tylko teoria, a praktyka wygląda inaczej. W takim przypadku dobrze, aby obywateli znali swoje prawa i obowiązki, by mogli ich wymagać od

${ }^{5}$ M. Borucka-Arctowa, Świadomość prawna a planowane zmiany społeczne, Zakład Narodowy im. Ossolińskich, Wrocław 1981, s. 10-11.

${ }^{6}$ Diagnoza świadomości prawnej Polaków 2016. Główne wyniki badania wizerunku wymiaru sprawiedliwości i wiedzy prawej Polaków, https://zpp.net.pl/files/manager/file-36173c331c1a3cefe77c4d166d459a2e.pdf [dostęp: 24.11.2019].

7 Tamże.

${ }^{8}$ Konstytucja Rzeczypospolitej Polskiej z dnia 2 kwietnia 1997 r., Dz.U. z 1997 r. nr 78, poz. 483.

${ }^{9}$ E. Gajda, B. Lubińska, Eacińska terminologia prawnicza, Wydawnictwo Dom Organizatora, Toruń 2014, s. 189.

${ }^{10}$ E. Kania, Czy warto uczyć prawa?, http://www.psep.pl/index.php?site=/czy warto uczyc prawa/ [dostęp: 10.02.2020].

${ }_{11}$ A. Grzelińska, Urzędnik pisze pismo. Ale o co mu chodzi? Język urzędowy, czyli niezrozumiały?, https://gazetawroclawska.pl/urzednik-pisze-pismo-ale-o-co-mu-chodzi-jezyk-urzedowy-czyliniezrozumialy/ar/10458738? fbclid=IwAR0YuvNQY--ZCnVsarTF3AQKV3cKDbvNkkMSWpzMSzW WB93CJ3knccNvkBw [dostęp: 28.11.2019]. 
osób mających wiedzę z danej dziedziny. Całej sytuacji nie ułatwia fakt, iż takie osoby jak prawnicy nie znają ponad 99\% obowiązujących przepisów w Polsce. Według P. Polańskiego z Akademii Leona Koźmińskiego w Warszawie głównym tego powodem jest obszerność przepisów (43 tysiące obowiązujących aktów z Dziennika Ustaw, 37 tysięcy aktów prawa europejskiego i 28 tysięcy przepisów materialnych) ${ }^{12}$. Według raportu GrantThornton tylko w 2017 roku w życie weszło 27118 stron maszynopisu nowych aktów prawnych, co i tak nie jest rekordowym wynikiem, gdyż wydano ich o $15 \%$ mniej niż w roku $2016^{13}$.

\section{Metodologia badań}

Celem prezentowanej analizy jest przedstawienie świadomości prawnej studentów Instytutu Prawa, Administracji i Ekonomii na Uniwersytecie Pedagogicznym im. Komisji Edukacji Narodowej w Krakowie. W ramach diagnozowania świadomości prawnej na zajęciach dla studentów pierwszego roku studiów stacjonarnych licencjackich oraz magisterskich kierunków prawo, administracja i ekonomia społeczna w wyżej wspomnianym instytucie zostały przeprowadzone anonimowe ankiety. Respondenci zostali dobrani w sposób celowy, gdyż artykuł ma za zadanie sprawdzenie, czy osoby, które są na etapie zdobywania wyższego wykształcenia, są świadome swoich praw i obowiązków, jakie na nich ciążą. W badaniu wzięło udział 187 studentów, w tym 147 kobiet oraz 40 mężczyzn. Studentów z kierunku administracja było 53, w tym 45 kobiet oraz 8 mężczyzn, z kierunku prawo - 86, w tym 62 kobiety i 24 mężczyzn, a z kierunku ekonomia społeczna - 48, w tym 40 kobiet oraz 8 mężczyzn. Jak już wspomniano, wszystkie osoby, które brały udział w ankiecie, to studenci pierwszego roku, co również jest celowym zabiegiem, mającym sprawdzić, jaką wiedzę wynieśli oni ze szkół średnich. Ankieta składała się z 15 pytań merytorycznych typu zamkniętego oraz 4 pytań metryczkowych dotyczących płci, kierunku studiów, roku studiów oraz tego, czy ktoś z rodziny badanego ma wykształcenie prawnicze. Pytania merytoryczne dotyczyły wiedzy prawnej z różnych obszarów - zarówno ekonomii, administracji, jak i prawa. Pytania opatrzone były czterema wariantami odpowiedzi, z których tylko jedna była poprawna. W przypadku gdy student nie znał odpowiedzi na pytanie, mógł zaznaczyć „nie wiem”.

\section{Świadomość prawna w opinii respondentów}

Spośród 15 pytań do analizy zostało wybranych sześć. Było to związane z tym, iż pytania te, według oceny autorów, są związane z codziennym funkcjonowaniem w społeczeństwie, przez co osoby z wykształceniem średnim nie powinny mieć większych problemów, aby

12 A. Łukaszewicz, Świadomość prawna Polaków - badanie Stowarzyszenia Sędziów Polskich Iustitia, https://www.rp.p1/Prawnicy/303089994-Swiadomosc-prawna-Polakow---badanie-Stowarzyszenia-Sedziow-Polskich-Iustitia.html [dostęp: 28.11.2019].

13 Produkcja prawa w Polsce spowolniła, ale nadal przyttacza. Barometr stabilności otoczenia prawnego w polskiej gospodarce, https://grantthornton.pl/wp-content/uploads/2018/02/Barometr-prawa-raport2018-GRANT-THORNTON-27-02-2018.pdf [dostęp: 10.02.2020]. 
odpowiedzieć na nie, gdyż podstawy prawa miały na zajęciach z wiedzy o społeczeństwie w gimnazjum oraz szkole średniej.

Fundamentalne pytanie prawne, które zostało zaprezentowane poniżej, dotyczy pełnej zdolności do czynności prawnych. Treść pytania oraz odpowiedzi zaprezentowane są w tabeli 1.

Tabela 1. Wiek osiągnięcia pełnej zdolność do czynności prawnych w opinii badanych $(n=187)$

\begin{tabular}{|l|c|c|c|c|}
\hline Kierunek & $\begin{array}{c}\text { W momencie } \\
\text { urodzenia }\end{array}$ & $\begin{array}{c}\text { Po ukończeniu } \\
\text { 13. roku życia }\end{array}$ & $\begin{array}{c}\text { Po ukończeniu } \\
\text { 18. roku życia }\end{array}$ & Nie wiem \\
\hline Administracja & $50,94 \%$ & $39,62 \%$ & $7,55 \%$ & $1,89 \%$ \\
\hline Prawo & $0,00 \%$ & $0,00 \%$ & $100,00 \%$ & $0,00 \%$ \\
\hline Ekonomia społeczna & $0,00 \%$ & $6,25 \%$ & $93,75 \%$ & $0,00 \%$ \\
\hline
\end{tabular}

Źródło: opracowane na podstawie badań własnych.

Tabela 1 prezentuje, iż studenci kierunku prawo jako jedyni w stu procentach poprawnie odpowiedzieli na pytanie, gdyż wybrali oni odpowiedź, że człowiek osiąga pełną zdolność do czynności prawnych po ukończeniu 18. roku życia, co znajduje odzwierciedlenie w Kodeksie cywilnym w art. 11, który brzmi: „Pełną zdolność do czynności prawnych nabywa się z chwilą uzyskania pełnoletności”" ${ }^{14}$. Pojęcie pełnoletności wyjaśnione jest w art $10 \S 1$ : „Pełnoletnim jest, kto ukończył lat osiemnaście”15. Nie jest to zaskoczeniem, gdyż studenci prawa na tym etapie kształcenia w swoim programie toku studiów mieli możliwość przypomnienia sobie tego zagadnienia na przedmiocie wstęp do prawoznawstwa. Najbardziej zaskakująco, w negatywnym znaczeniu tego słowa, wypadli studenci kierunku administracja, gdyż ponad 50\% odpowiedziało, że człowiek osiąga tę zdolność w momencie urodzenia, tylko 7,55\% poprawnie odpowiedziało na to pytanie, co jest kolejnym zaskoczeniem, gdyż administracja na tym etapie kształcenia ma zbliżony program nauczania do kierunku prawo (analogicznie do niego ma prowadzony przedmiot wstęp do prawoznawstwa). Wynik studentów ekonomii społecznej można uznać za dobry, ponieważ aż 93,75\% z nich wybrało poprawną odpowiedź, choć zagadnienia związane z prawem nie są głównym przedmiotem ich zainteresowania. Mimo takiego ukierunkowania niezbędna jest tutaj znajomość nie tylko procesów ekonomicznych czy społecznych, lecz także przepisów prawa, które w dużej mierze wpływają na te procesy. Ekonomię społeczną postrzega się najczęściej jako dziedzinę aktywności społecznej nieprzynależnej rynkowi i państwu. J. Hausner przyjmuje, że jest ona sektorem gospodarki, w którym organizacje są ukierunkowane na społeczną użyteczność, a co za tym idzie - wypracowana przez nie nadwyżka służy realizacji celu społecznego ${ }^{16}$.

Kolejne pytanie dotyczyło prawa konsumentów. Brzmiało ono następująco: „Kogo obowiązuje rękojmia?”. Tabela 2 prezentuje wyniki, które nie są jednoznaczne.

\footnotetext{
${ }^{14}$ Ustawa z dnia 23 kwietnia 1964 r. - Kodeks cywilny, tekst jedn. Dz.U. z 2019 r., poz. 1145 ze zm.

15 Tamże.

16 M. Małecka-Łyszczek, Podmioty ekonomii społecznej jako podmioty administrujące, „Zeszyty Naukowe UEK. Problemy Społeczne, Polityczne i Prawne” 2013, nr 917, s. 75.
} 
Tabela 2. Obowiązywanie rękojmi w opinii badanych $(n=187)$

\begin{tabular}{|l|c|c|c|c|}
\hline \multicolumn{1}{|c|}{ Treść odpowiedzi } & Producenta & Sprzedawce & $\begin{array}{c}\text { Producenta } \\
\text { i sprzedawcę }\end{array}$ & Nie wiem \\
\hline Administracja & $9,43 \%$ & $35,85 \%$ & $24,53 \%$ & $30,19 \%$ \\
\hline Prawo & $6,98 \%$ & $33,72 \%$ & $37,21 \%$ & $22,09 \%$ \\
\hline Ekonomia społeczna & $6,25 \%$ & $37,50 \%$ & $27,08 \%$ & $29,17 \%$ \\
\hline
\end{tabular}

Źródło: opracowane na podstawie badań własnych.

Poprawna odpowiedź na to pytanie brzmi: rękojmia obowiązuje tylko i wyłączenie sprzedawcę. W tym zestawieniu najlepiej zaprezentowała się ekonomia społeczna, gdyż poprawne odpowiedzi stanowiły aż 37,5\%. Drugie miejsce zajęła administracja z wynikiem $35,85 \%$, na ostatnim miejscu uplasowało się prawo z wynikiem 33,72\%. Warto zwrócić uwagę, iż duży odsetek osób wybrało wariant odpowiedzi „,nie wiem”, co pokazuje, że młode społeczeństwo nie ma wiedzy dotyczącej praw konsumentów, która może być przydatna w życiu codziennym.

Kolejne pytanie brzmiało: „Kto odpowiada za zalanie lokalu z powodu pęknięcia wężyka?". Zostało ono skierowane do studentów, gdyż wielu z nich wynajmuje mieszkania, przez co mogą zetknąć się z taką sytuacją w praktyce.

Tabela 3. Ponoszenie odpowiedzialności przez właściciela lokalu według opinii badanych $(n=187)$

\begin{tabular}{|l|c|c|c|c|}
\hline Treść odpowiedzi & $\begin{array}{c}\text { Właściciel lokalu, } \\
\text { w którym pękł wę- } \\
\text { żyk, bez potrzeby } \\
\text { udowadniania } \\
\text { winy }\end{array}$ & $\begin{array}{c}\text { Właściciel lokalu, } \\
\text { w którym pękł } \\
\text { wężyk, o ile } \\
\text { udowodni mu się } \\
\text { winę }\end{array}$ & $\begin{array}{c}\text { Właściciel } \\
\text { lokalu, jeżeli } \\
\text { wężyk montował } \\
\text { samodzielnie }\end{array}$ & Nie wiem \\
\hline Administracja & $35,85 \%$ & $32,08 \%$ & $24,53 \%$ & $7,55 \%$ \\
\hline Prawo & $36,05 \%$ & $52,33 \%$ & $4,65 \%$ & $8,14 \%$ \\
\hline Ekonomia społeczna & $37,50 \%$ & $37,50 \%$ & $16,67 \%$ & $8,33 \%$ \\
\hline
\end{tabular}

Źródło: opracowane na podstawie badań własnych.

Po raz kolejny studenci kierunku ekonomia społeczna poradzili sobie najlepiej z pytaniem z zakresu wiedzy praktycznej, ponieważ odsetek poprawnych odpowiedzi stanowił 37,5\%. Na kolejnym miejscu uplasowali się studenci prawa - z wynikiem 36,05\%. Ostatni byli studenci administracji - z wynikiem 35,85\%. W tym pytaniu różnice między poszczególnymi kierunkami były nieznaczne, co jest dobrym sygnałem, iż młodzi ludzie, którzy dopiero wchodzą w dorosłe życie, w przyszłości będą znali schemat postępowania w przypadku nieszczęśliwych zdarzeń losowych.

Czwarte pytanie związane było z wiedzą z zakresu prawa pracy. Brzmiało ono: „Ile lat musi posiadać młodociany, aby podjąć legalną pracę według Kodeksu pracy?”. Nie powinno ono sprawić trudności studentom, ponieważ wielu z nich przed ukończeniem 18. roku życia podejmowało pracę (najczęściej była to praca sezonowa). 
Tabela 4. Podjęcie pracy przez młodocianego według opinii badanych $(n=187)$

\begin{tabular}{|l|c|c|c|c|}
\hline \multicolumn{1}{|c|}{ Treść odpowiedzi } & $\mathbf{1 7}$ lat & $\mathbf{1 6}$ lat & $\mathbf{1 8}$ lat & Nie wiem \\
\hline Administracja & $1,89 \%$ & $83,02 \%$ & $15,09 \%$ & $0,00 \%$ \\
\hline Prawo & $0,00 \%$ & $93,02 \%$ & $5,81 \%$ & $1,16 \%$ \\
\hline Ekonomia społeczna & $6,25 \%$ & $72,92 \%$ & $16,67 \%$ & $4,17 \%$ \\
\hline
\end{tabular}

Źródło: opracowane na podstawie badań własnych.

Odpowiedzi na to pytanie na każdym kierunku wypadły dobrze, gdyż studenci wiedzieli, że aby legalnie pracować, trzeba mieć 16 lat. W pytaniu padło słowo „młodociany”, a według art. $190 \S 1$ Kodeksu pracy: „Młodocianym w rozumieniu kodeksu jest osoba, która ukończyła 15 lat, a nie przekroczyła 18 lat" ${ }^{17}$. Wśród badanych najlepiej wypadli studenci prawa ze znaczącą różnicą 10 punktów procentowych w stosunku do administracji, która osiągnęła wyniki 83,02\% i prawie 20 punktów procentowych w stosunku do ekonomii społecznej, która uzyskała wynik 72,92\%.

Pytanie piąte dotyczyło wiedzy teoretycznej z Kodeksu wyborczego. Brzmiało ono następująco: „Czy osoba po ukończeniu 18. roku życia może kandydować do Sejmu RP?”

Tabela 5. Cenzus wieku do Sejmu RP według opinii badanych $(n=187)$

\begin{tabular}{|l|c|c|c|c|}
\hline Treść odpowiedzi & $\begin{array}{c}\text { Tak, może kandy- } \\
\text { dować, jeśli przed- } \\
\text { stawi poręczenie } \\
\text { majątkowe }\end{array}$ & $\begin{array}{c}\text { Tak, może } \\
\text { kandydować }\end{array}$ & $\begin{array}{c}\text { Nie, nie może } \\
\text { kandydować }\end{array}$ & Nie wiem \\
\hline Administracja & $3,77 \%$ & $11,32 \%$ & $77,36 \%$ & $5,66 \%$ \\
\hline Prawo & $0,00 \%$ & $3,49 \%$ & $95,35 \%$ & $1,16 \%$ \\
\hline Ekonomia społeczna & $0,00 \%$ & $33,33 \%$ & $58,33 \%$ & $8,33 \%$ \\
\hline
\end{tabular}

Źródło: opracowane na podstawie badań własnych.

Studenci prawa w pytaniu piątym wykazali się najlepszą wiedzą teoretyczną, bo poprawnie odpowiedzieli na to pytanie w 95,35\%, ponieważ wybrali odpowiedź, która brzmiała następująco: „Do Sejmu RP nie może kandydować osoba, która ukończyła 18. rok życia”. Według art. $11 \S 1$ pkt 1 Kodeksu wyborczego może to być „obywatel polski mający prawo wybierania w tych wyborach, który najpóźniej w dniu wyborów kończy 21 lat"18. Taką odpowiedź wybrało 77,36\% studentów kierunku administracja oraz 58,33\% studentów kierunku ekonomia społeczna. Jeśli chodzi o studentów kierunku ekonomia społeczna, na etapie piątego pytania można wyciągnąć częściowy wniosek, iż najlepiej radzą sobie oni z pytaniami o podłożu praktycznym, a nie teoretycznym, co z kolei wiąże się bezpośrednio $\mathrm{z}$ ich kierunkiem studiów oraz zainteresowaniami.

Pytanie szóste po raz kolejny związane było zagadnieniami z Kodeksu pracy. Dotyczyło ono zawarcia umowy pomiędzy pracodawcą a pracownikiem po raz trzeci, na czas określony.

\footnotetext{
17 Ustawa z dnia 26 czerwca 1974 r. - Kodeks pracy, tekst jedn. Dz.U. z 2019 r., poz. 1040 ze zm.

18 Ustawa z dnia 5 stycznia 2011 r. - Kodeks wyborczy, tekst jedn. Dz.U. z 2019 r., poz. 684 ze zm.
} 
Tabela 6. Zawarcie umowy na czas nieokreślony według opinii badanych $(n=187)$

\begin{tabular}{|l|c|c|c|c|}
\hline Kierunek & $\begin{array}{c}\text { Umowa na czas } \\
\text { określony }\end{array}$ & $\begin{array}{c}\text { Umowa na czas } \\
\text { nieokreślony }\end{array}$ & Umowa zlecenie & Nie wiem \\
\hline Administracja & $24,53 \%$ & $33,96 \%$ & $20,75 \%$ & $20,75 \%$ \\
\hline Prawo & $31,40 \%$ & $38,37 \%$ & $10,47 \%$ & $19,77 \%$ \\
\hline Ekonomia społeczna & $33,33 \%$ & $29,17 \%$ & $29,17 \%$ & $8,33 \%$ \\
\hline
\end{tabular}

Źródło: opracowane na podstawie badań własnych.

Tabela 6 ukazuje, iż wyniki rozłożyły się proporcjonalnie pomiędzy wszystkimi wariantami odpowiedzi. Prawidłowa odpowiedź jest zawarta w Kodeksie pracy w art. $25 \S 1$ i brzmi następująco: „Okres zatrudnienia na podstawie umowy o pracę na czas określony [...] a łączna liczba tych umów nie może przekraczać trzech ${ }^{19}$. Najlepiej odpowiedzieli studenci prawa - aż 38,37\% z nich wiedziało, że umowa zawarta po raz trzeci staje się umową na czas nieokreślony, 31,4\% uważało, iż nadal jest to umowa na czas określony, 10,47\% wybrało odpowiedź umowa zlecenie, a 19,77\% wskazało, że nie zna odpowiedzi na to pytanie. Studenci administracji wpadli gorzej o niecałe 5 punktów procentowych od kierunku prawo, uzyskując wynik 33,96\%, 24,53\% wskazało odpowiedź ,umowa na czas określony”, 20,75\% zaznaczyło odpowiedź ,umowa zlecenie”, a identyczna liczba studentów uznała, że nie zna odpowiedzi na to pytanie. Ekonomia społeczna wypadła najgorzej w całym zestawieniu. Poprawnej odpowiedzi udzieliło tylko 29,17\% studentów, tyle samo stwierdziło, że staje się umową zleceniem, najwięcej uważało, iż jest to kolejna umowa na czas określony, 8,33\% twierdziło natomiast, że nie zna odpowiedzi na to pytanie. Było to pytanie z pogranicza praktyki i teorii, jednak żaden z wyżej wymienionych kierunków nie poradził sobie z nim w sposób odpowiadający oczekiwaniom. Jest to przykład pytania, gdzie wyniki są zaskakujące - w negatywnym znaczeniu tego słowa, gdyż prawdopodobnie studenci podejmowali różnego rodzaju prace, np. pracę sezonową, podczas której zawierali umowy z pracodawcą. Dlatego dziwi tak niska znajomość rodzaju umów w polskim systemie prawnym. Warto przypomnieć, iż w Kodeksie pracy wyróżniamy następujące umowy: umowę na okres próbny, umowę na czas określony, umowę na czas nieokreślony, umowę na zastępstwo, umowę o dzieło, umowę zawieraną na podstawie Kodeksu cywilnego oraz umowę zlecenie ${ }^{20}$.

Warto zwrócić uwagę na prezentację wyników całości ankiety na poszczególnych kierunkach.

${ }^{19}$ Ustawa z dnia 26 czerwca 1974 r. - Kodeks pracy, tekst jedn. Dz.U. z 2019 r., poz. 1040 ze zm.

${ }^{20}$ Tamże. 


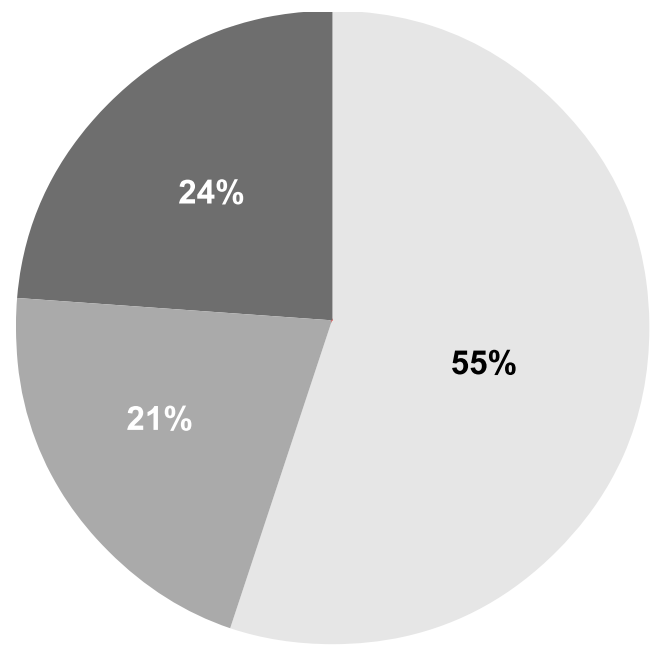

prawo

ekonomia społeczna

administracja

Rysunek 1. Odsetek poprawnych odpowiedzi udzielanych przez ankietowanych z poszczególnych kierunków $(n=187)$

Źródło: opracowanie na podstawie własnych badań.

Rysunek 1 obrazuje wyniki poprawnych odpowiedzi na wszystkie pytania. Nie jest dużym zaskoczeniem, że studenci prawa w całym zestawieniu wypadli najlepiej, odpowiadając na 55\% pytań poprawnie. Na drugim miejscu w ogólnym rankingu uplasowali się studenci administracji-z wynikiem 24\%. Studenci ekonomii społecznej w tym zestawieniu wypadli najsłabiejz wynikiem $21 \%$. Autorki nie koncentrowały sięjednak na wszystkich pytaniach z ankiety, lecz tylko na wyżej omówionych kwestiach. Jeżeli chodzi o odpowiedzi na sześć wybranych pytań, studenci administracji ani razu nie uplasowali się na pierwszym miejscu, mimo iż ich program studiów na tym etapie kształcenia jest zbliżony do programu studentów prawa. Najbardziej widoczne to jest w pytaniu o pełną zdolność do czynności prawnych, gdzie tylko 7,55\% studentów kierunku administracji odpowiedziało poprawnie, a studenci prawa w $100 \%$. Studenci ekonomii społecznej zaprezentowali się podobnie, a nawet lepiej od studentów administracji, mimo znacznej różnicy programu kształcenia, gdyż dwukrotnie uplasowali się na pierwszym miejscu w pytaniach, które mają przełożenie na płaszczyznę życia codziennego.

\section{Zakończenie}

Reasumując, można stwierdzić, że świadomość prawna studentów pierwszego roku prawa, administracji i ekonomii społecznej w Instytucie Prawa, Administracji i Ekonomii w Uniwersytecie Pedagogicznym im. Komisji Edukacji Narodowej w Krakowie na początkowym etapie ich kształcenia jest stosunkowo dobra, gdyż niektóre pytania zawarte w ankiecie były szczegółowe. Z przedstawionych wyników można wysunąć wniosek, że studenci - jako przedstawiciele osób, które są na etapie zdobywania wyższego wykształcenia - lepiej poradzili sobie z pytaniami natury teoretycznej niż praktycznej, ale próba badawcza stanowiła 
zaledwie wycinek całego społeczeństwa akademickiego z kierunków społecznych. W artykule zostały przeprowadzone badania diagnostyczne. Autorki są świadome, iż podanych wyników nie można generalizować na skalę całego kraju - uzyskane wyniki są tylko podstawą do dalszych badań w tym zakresie. Przedstawione badania mogą również stanowić inspirację do zmiany programów nauczania w szkołach wyższych, a przede wszystkim w szkołach średnich, gdzie nie ma przedmiotów typu podstawy prawa, a edukacja prawna - prowadzona przez takie stowarzyszenia jak Iustitia - jest niewystarczająca, ponieważ obejmuje tylko kilkanaście szkół z wybranego regionu Polski²1.

\section{Bibliografia}

Borucka-Arctowa M., Świadomość prawna a planowane zmiany społeczne, Zakład Narodowy im. Ossolińskich, Wrocław 1981.

Czapska J., Psychospoleczne wątki w pracach Marii Boruckiej-Arctowej. Świadomość prawna, Zakład Wydawniczy Nomos Sp. z o.o., Kraków 2017.

Diagnoza świadomości prawnej Polaków 2016. Główne wyniki badania wizerunku wymiaru sprawiedliwości $i$ wiedzy prawej Polaków, https://zpp.net.pl/files/manager/file-36173c331c1a3cefe77c4d166d459a2e.pdf [dostęp: 24.11.2019].

Gajda E., Lubińska B., Łacińska terminologia prawnicza, Wydawnictwo Dom Organizatora, Toruń 2014.

Grzelińska A., Urzędnik pisze pismo. Ale o co mu chodzi? Język urzędowy, czyli niezrozumiaty?, https://gazetawroclawska.pl/urzednik-pisze-pismo-ale-o-co-mu-chodzi-jezyk-urzedowy -czyli-niezrozumialy/ar/10458738?fbclid=IwAR0YuvNQY--ZCnVsarTF3AQKV3cKDbvNkkMSWpzMSzWWB93CJ3knccNvkBw [dostęp: 28.11.2019].

Kania E., Czy warto uczyć prawa?, http://www.psep.pl/index.php?site=/czy warto uczyc prawa/ [dostęp: 10.02.2020].

Kuryłowicz M., Słownik terminów, zwrotów i sentencji prawniczych łacińskich oraz pochodzenia tacińskiego, Wolters Kluwer, Warszawa 2012.

Łukaszewicz A., Świadomość prawna Polaków - badanie Stowarzyszenia Sędziów Polskich Iustitia, https://www.rp.pl/Prawnicy/303089994-Swiadomosc-prawna-Polakow---badanie-Stowarzyszenia-Sedziow-Polskich-Iustitia.html [dostęp: 28.11.2019].

Małecka-Łyszczek M., Podmioty ekonomii społecznej jako podmioty administrujące, „Zeszyty Naukowe UEK. Problemy Społeczne, Polityczne i Prawne” 2013, nr 917.

Petrażycki L., O pobudkach postępowania i o istocie moralności i prawa, Oficyna Naukowa, Warszawa 2002.

Produkcja prawa $w$ Polsce spowolniła, ale nadal przytłacza. Barometr stabilności otoczenia prawnego w polskiej gospodarce, https:/grantthornton.pl/wp-content/uploads/2018/02/Barometr-prawa-raport-2018-GRANT-THORNTON-27-02-2018.pdf [dostęp: 10.02.2020].

Sprawozdanie z realizacji projektu „Edukacja prawna młodzieży, https://www.iustitia.pl/wroclaw/index.php/nasze-prace/edukacja-prawna-mlodziezy [dostęp: 10.02.2020].

${ }^{21}$ Sprawozdanie z realizacji projektu ,Edukacja prawna młodzieży”, https://www.iustitia.pl/wroclaw/ index.php/nasze-prace/edukacja-prawna-mlodziezy [dostęp: 10.02.2020]. 


\section{Akty prawne}

Konstytucja Rzeczypospolitej Polskiej z dnia 2 kwietnia 1997 r., Dz.U. z 1997 r. nr 78, poz. 483.

Ustawa z dnia 23 kwietnia 1964 r. - Kodeks cywilny, tekst jedn. Dz.U. z 2019 r., poz. 1145 ze zm.

Ustawa z dnia 26 czerwca 1974 r. - Kodeks pracy, tekst jedn. Dz.U. z 2019 r., poz. 1040 ze zm.

Ustawa z dnia 5 stycznia 2011 r. - Kodeks wyborczy, tekst jedn. Dz.U. z 2019 r., poz. 684 ze zm. 